\title{
Efficacy of Some Organic Amendments for the Control of Stem and Bulb Nematode, Ditylenchus dipsaci (Kühn) Filipjev on Garlic (Allium sativum)
}

\author{
M. R. M. Saeed \\ Department of Plant Protection, Faculty of Agriculture, Sana'a University, Yemen. \\ E. mail: raweh2001@yahoo.com
}

\begin{abstract}
A greenhouse experiment was conducted to evaluate effect of some soil amendments, i.e; fresh chopped leaves or dry leaves powder of Datura stramonium, Peganum harmala or Tagetes minuta, poultry and sheep manure in controlling the stem and bulb nematode, Ditylenchus dipsaci on garlic (Allium sativum) as compared to the nematicide, Vydate ${ }^{\circledR}(O x a m y l)$. All applied treatments significantly $(P \leq 0.05)$ reduced final population of $D$. dipsaci except in treatment of sheep manure at lowest dosage rate, which significantly increased the population in comparison to that of the check. Efficacy of the treatments differed according to the type of organic soil amendment, dosage rate and type of application. Dry leaves powder of Peganum harmala was the most effective in reducing nematode counts in soil and garlic bulbs at the different rates, followed by fresh chopped leaves of Datura stramonium and $T$. minuta while, the lowest \% reduction in such nematode parameters was recorded in case of soil amended with sheep manure followed by dry leaves powder of Datura stramonium. As for plant growth criteria the results reveal that most tested materials improved plant growth criteria of shoot, root and bulb compared to the untreated controls.
\end{abstract}

Keywords: Ditylenchus dipsaci, nematicides, botanical amendments, organic manures, garlic.

\section{Introduction}

The stem and bulb nematode, Ditylenchus dipsaci (Kühn) Filipjev is a serious pest of commercial garlic and onion in the colder regions. In temperate regions it is among the plant-parasitic nematodes of greatest economic impact. $D$. dipsaci is known to attack over 450 different plant species, including many weeds. However, it occurs in more than ten biological "races" some of which have a limited host range.

In Yemen, garlic and onion are the major hosts of D. dipsaci, causing complete failure of host crops when neglecting control procedures (Awadh et al., 2008). D. dipsaci infections can arise from planting in nematode-infested soil or more commonly from planting infected garlic seed cloves. Damages by $D$. dipsaci 
are usually necrosis or rotting of bulbs, swellings and distortion of aerial plant parts, leaf yellowing and death of young plants. Chemical nematicides are effective in management of nematode problems, but their hazardous effect on human health, environment, ground water contamination and non-target organisms could limit its use (Whitehead, 1998; Giannakou et al., 2004; Tsayet al., 2004; Anastasiadis et al., 2008 and Washira et al., 2009).

This has encouraged scientists to search for alternative sources of effective, cheap, eco-friendly and harmless methods for nematode control (Noling and Becker, 1994 and Chitwood, 2003). Plant extracts of some plants have been tested for nematicidal activity against $D$. dipsaci in vitro and in soil (Insunza, 1988 and 1994; Insunza and Valenzuela, 1995; Awadh et al., 2008; Zouhar et al., 2009 and Hassan, et al., 2015). Soil amendments with fresh chopped or dry ground leaves of plants, poultry manure and sheep manure have been successfully used for the control of plant-parasitic nematodes and improve plant growth. However, the most researches were focused on the root-knot nematodes, Meloidogyne spp. (Muller and Gooch, 1982; Alam, 1990; Akhtar and Mahmood, 1996; Nahar et al., 1996; Akhtar and Malik, 2000; Kheir, et al., 2000; Sundararaju et al., 2003; Verma, andKhan, 2004; Abdul Latif, et al., 2006; Wani, 2006; Ahmad, et al., 2007; Ibrahim, et al., 2007; Radwan, et al., 2007; Rather, et al., 2008; Ibrahim and Traboulsi, 2009; Kagai, 2009; Hussain, et al., 2011; Karmani et al., 2011; Moosavi, 2012; Parihar et al., 2012; Ishaku and Ahaji, 2013; Ojo and Umar, 2013; Youssef and Lashein, 2013 and Saeed and Shawkat, 2014).

The objective of this research was to evaluate the efficacy of soil organic amendments with fresh chopped leaves and dry leaves powder of three plant species (Datura stramonium, Peganum harmala and Tagetes minuta), poultry and sheep manures on the control of stem and bulb nematode, $D$. dipsaci infecting garlic under greenhouse conditions.

\section{Materials and Methods}

\section{Collection and Preparation of Leaves and Manures:}

Leaves of Datura stramonium, Peganum harmala and Tagetes minuta were separately collected during summer of 2011 from different plants of different locations at Sana'a University, Yemen. The leaves were air-dried on laboratory benches in the Department of Plant Protection for 2 weeks at $20-30^{\circ} \mathrm{C}$. Then they were ground separately into fine powders with Thomas Wiley laboratory mill and electric Warring blinder and stored in a sealed container until using. The fresh leaves were washed in tap water and then finely chopped into very fine pieces. Dried chicken and sheep manures were obtained from research farm of the Faculty of Agriculture, ground and sieved over a $0.5-\mathrm{cm}$ sieve. 


\section{Preparation of Inoculum:}

The stem and bulb nematode inocula were obtained from bulbs of a highly infested commercial garlic field, which were extracted as previously described by Southey (1986) and OEPP/EPPO Bulletin (2008). The extracted nematodes were identified and then counted using a stereoscopic microscope.

\section{Greenhouse Experiment:}

Balady garlic cloves with uniform size were individually planted in $15-\mathrm{cm}$. diameter plastic pots filled with steam sterilized loamy sand soil (3:1, w:w). Plants were grown at natural photoperiod in a greenhouse for 2 weeks at a constant temperature of $20^{\circ} \mathrm{C} \pm 5$ and the uniform plants were then selected for treatment application later. Two weeks old garlic plants were inoculated with 500 nematodes of mixed life stages by pipetting $5 \mathrm{ml}$ aqueous suspensions of the nematodes into 5 holes in the soil around the roots; and the holes were immediately filled with moist soil. Five plants were kept without inoculation to serve as a healthy check treatment. Ten days after inoculation 5, 10 and $15 \mathrm{~g}$ (equilvalent to 5.7, 11.4 and $17.1 \mathrm{t} / \mathrm{ha}$, respectively) of fresh chopped leaves or dry leaves powder were incorporated on top of soil around the base of each plant. Poultry and sheep manures were applied at the rate of 5,10 and $15 \mathrm{~g} /$ pot; while $V y d a t e \AA ~(o x a m y l)$ was used at the rate of $1 \mathrm{gm} /$ pot as a comparable treatment. Some pots of nematode-inoculated plants were kept without materials application to serve as a check. Each treatment was replicated 5 times and all pots were arranged in a randomized block design on a greenhouse bench at temperature degrees of $20^{\circ} \mathrm{C} \pm 5$. All plants received similar treatments of fertilizing and irrigation. Sixty days after inoculation, the experiment was ended and all plants were rooted-off and nematode counts in both soil and plants were estimated. Plant growth criteria on the basis of shoot and root lengths; and shoot, root and bulb fresh weights were measured. Data were subjected to analysis of variance and means were compared at $\mathrm{P} \leq 0.05$ using SPSS software version 21.

\section{Results}

Data in Table (1) indicate that all applied treatments significantly $(P \leq 0.05)$ reduced final population of $D$. dipsaci except that of sheep manure at the lowest dosage rate, which significantly increased the population in comparison to that of the check. Efficacy of the treatments differed according to the type of organic soil amendment, dosage rate and method of application. Generally, by increasing the amendment dosage rate, the efficacy was also increased. Dry leaves powder of $P$. harmala was more effective in reducing the nematode population than fresh chopped leaves, but the reverse was true for $D$. stramonium and $T$. minuta. Dry leaves powder of $P$. harmala was the most effective in reducing nematode counts in soil and garlic bulbs with all rates, followed by fresh chopped leaves of $D$. stramonium and T. minuta. 
Table (1): Effect of organic soil amendments on population of Ditylenchus dipsaci infecting garlic plants under greenhouse conditions.

\begin{tabular}{|c|c|c|c|c|c|c|c|}
\hline \multirow[b]{2}{*}{ Treatments } & \multicolumn{3}{|l|}{ Dose } & \multicolumn{3}{|c|}{ Nematode counts } & \multirow[b]{2}{*}{ Build up } \\
\hline & gm. & In Soil & \%Reduction & In Plant & \%Reduction & $\begin{array}{c}\text { Final } \\
\text { population }\end{array}$ & \\
\hline \multirow{3}{*}{$\begin{array}{c}\text { Datura } \\
\text { stramonium } \\
\text { (F) }\end{array}$} & 5 & 274.0 efg & 44.0 & $179.6 \mathrm{abcd}$ & 89.7 & 453.6 bcde & 0.9 \\
\hline & 10 & 206.2 cdef & 57.8 & $228.1 \mathrm{abcd}$ & 86.9 & $434.3 \mathrm{bcd}$ & 0.9 \\
\hline & 15 & $104.8 \mathrm{abcd}$ & 78.6 & $135.0 \mathrm{abc}$ & 92.2 & $239.8 \mathrm{abc}$ & 0.5 \\
\hline \multirow{3}{*}{$\begin{array}{c}\text { Datura } \\
\text { stramonium } \\
\text { (D) }\end{array}$} & 5 & $559.3 \mathrm{jk}$ & -14.4 & 680.2 efgh & 60.9 & $1239.5 \mathrm{~h}$ & 2.5 \\
\hline & 10 & $421.5 \mathrm{hi}$ & 13.8 & 528.5 defg & 69.6 & $950.0 \mathrm{gh}$ & 1.9 \\
\hline & 15 & $323.7 \mathrm{fgh}$ & 33.8 & $233.4 \mathrm{abcd}$ & 86.6 & $557.1 \mathrm{cdef}$ & 1.1 \\
\hline \multirow{3}{*}{$\begin{array}{l}\text { Peganum } \\
\text { harmala } \\
\text { (F) }\end{array}$} & 5 & 237.6 def & 51.4 & 945.2 hi & 45.7 & $1182.8 \mathrm{~h}$ & 2.4 \\
\hline & 10 & $398.0 \mathrm{ghi}$ & 18.6 & 440.0 bcde & 74.7 & 838.0 efgh & 1.7 \\
\hline & 15 & $196.0 \mathrm{cdef}$ & 59.9 & $300.8 \mathrm{abcd}$ & 82.7 & 496.8 bcde & 1.0 \\
\hline \multirow{3}{*}{$\begin{array}{l}\text { Peganum } \\
\text { harmala } \\
\text { (D) }\end{array}$} & 5 & $118.0 \mathrm{abcd}$ & 75.9 & $295.0 \mathrm{abcd}$ & 83.0 & $413.0 \mathrm{bcd}$ & 0.8 \\
\hline & 10 & $0.0 \mathrm{a}$ & 100.0 & $208.1 \mathrm{abcd}$ & 88.0 & $208.1 \mathrm{abc}$ & 0.4 \\
\hline & 15 & $0.0 \mathrm{a}$ & 100.0 & $0.0 \mathrm{a}$ & 100.0 & $0.0 \mathrm{a}$ & 0.0 \\
\hline \multirow{3}{*}{$\begin{array}{l}\text { Tagetes } \\
\text { minuta } \\
\text { (F) }\end{array}$} & 5 & $303.2 \mathrm{fgh}$ & 38.0 & $835.1 \mathrm{fghi}$ & 52.0 & $1138.3 \mathrm{~h}$ & 2.3 \\
\hline & 10 & $106.0 \mathrm{abcd}$ & 78.3 & $229.0 \mathrm{abcd}$ & 86.8 & $335.0 \mathrm{abcd}$ & 0.7 \\
\hline & 15 & $52.2 \mathrm{ab}$ & 89.3 & $150.4 \mathrm{abcd}$ & 91.4 & $202.6 \mathrm{abc}$ & 0.4 \\
\hline \multirow{3}{*}{$\begin{array}{l}\text { Tagetes } \\
\text { minuta } \\
\text { (D) }\end{array}$} & 5 & 244.0 def & 50.1 & $877.2 \mathrm{ghi}$ & 49.6 & $1121.2 \mathrm{~h}$ & 2.2 \\
\hline & 10 & 196.4 cdef & 59.8 & 718.7 efghi & 58.7 & $915.1 \mathrm{fgh}$ & 1.8 \\
\hline & 15 & 150.2 bcde & 69.3 & 499.9 cdef & 71.3 & $650.1 \mathrm{defg}$ & 1.3 \\
\hline \multirow{3}{*}{$\begin{array}{l}\text { Poultry } \\
\text { manure }\end{array}$} & 2 & 160.0 bcde & 67.3 & $922.3 \mathrm{hi}$ & 47.0 & $1082.3 \mathrm{~h}$ & 2.2 \\
\hline & 4 & $78.2 \mathrm{abc}$ & 84.0 & $841.6 \mathrm{fghi}$ & 51.6 & $919.8 \mathrm{fgh}$ & 1.8 \\
\hline & 6 & $89.0 \mathrm{abc}$ & 81.8 & $892.5 \mathrm{ghi}$ & 48.7 & $981.5 \mathrm{gh}$ & 2.0 \\
\hline \multirow{3}{*}{$\begin{array}{l}\text { Sheep } \\
\text { manure }\end{array}$} & 5 & 1114.0 I & -127.8 & $1931.6 \mathrm{j}$ & -11.0 & $3045.6 \mathrm{k}$ & 6.1 \\
\hline & 10 & $663.2 \mathrm{k}$ & -35.6 & $1078.4 \mathrm{i}$ & 38.0 & $1741.6 \mathrm{i}$ & 3.5 \\
\hline & 15 & 233.0 def & 52.4 & $968.6 \mathrm{hi}$ & 44.3 & $1201.6 \mathrm{~h}$ & 2.4 \\
\hline Oxamyl & 1 & $0.0 \mathrm{a}$ & 100.0 & $97.4 \mathrm{ab}$ & 94.4 & $97.4 a b$ & 0.2 \\
\hline Check & & $489.0 \mathrm{ij}$ & 0.0 & $1739.6 \mathrm{j}$ & 0.0 & $2228.6 \mathrm{j}$ & 4.5 \\
\hline
\end{tabular}

Means followed by the same letter(s) within a column are not significantly different $(p \leq 0.05)$ according to Duncan's multiple range test.

$\mathrm{F}=$ Fresh chopped leaves.

$D=$ Dry leaves powder.

While, the lowest \% reduction in nematode counts was recorded in treatment of soil amended with sheep manure followed by those of dry leaves powder of $D$. stramonium and poultry manure. Insignificant differences were observed in nematode counts in soil between the check and those treated with fresh chopped leaves of $P$. harmala at modest dosage rate, and dry leaves powder of $D$. 
stramonium at lowest and modest dosage rates. In contrast, sheep manure at lowest and modest dosage rates caused significant increase in nematode counts in soil.

Highest \% reduction (100\%) in nematode counts in soil was achieved by dry leaves powder of $P$. harmala at modest and highest dosage rates as well as Vydate ${ }^{\circledR}$ (Oxamyl). In general, all treatments significantly succeeded in reducing counts of nematode in garlic bulbs, except in treatment of sheep manure at lowest dosage rate. Likely, dry leaves powder of $P$. harmala at the highest dosage rate achieved $100 \%$ nematode reduction in garlic bulbs, followed by "Vydate®" $(94.4 \%)$ and highest dosage rate of fresh chopped leaves of $D$. stramonium $(92.2 \%)$ and then T. minuta (91.4\%). Accordingly, the nematode final population and its rate of build-up of all treatments - except those of sheep manure at lowest dosage rate were significantly differed from those of the check. Comparatively, all dosage rates of $P$. harmala dry leaves powder achieved the lowest rates of build-up $(0.0,0.4$ and $0.8)$, followed by that of "Vydate ${ }^{\circledR} "(0.2)$. Almost, similar results were obtained by fresh chopped leaves of $T$. minuta $(0.4$ and 0.7$)$ and $D$. stramonium $(0.5$ and 0.9$)$ at highest and modest dosage rates. In contrast, sheep manure at different dosage rates caused the highest values of build up, (6.1, 3.5 and 2.4).

As for plant growth criteria, data presented in Table (2), reveal that most applied amendments improved growth of shoots, roots and bulbs of garlic. Relatively, remarkable increases were noticed in weights than in lengths of shoots than in roots. Significant increase in shoot fresh weight was obtained by most treatments except in case of fresh chopped leaves of $P$. harmala and sheep manure at different dosage rates, lowest dosage rate of dry leaves powder of $P$. harmala and $D$. stramonium, lowest dosage rate of fresh chopped leaves of $D$. stramonium and lowest and highest dosage rate of fresh chopped leaves of $T$. minuta. The highest \% increase in shoot fresh weight was recorded in plants treated with fresh chopped leaves of $D$. stramonium at highest dosage rate $(282.3 \%)$, followed by those of $V y d a t e \circledR(254.5 \%)$, dry leaves powder of $T$. minuta at modest dosage rate $(248.4 \%)$ and poultry manure at modest dosage rate $(209.7 \%)$.Shoot length was significantly increased in all treatments except in treatments of fresh chopped leaves of $P$. harmala at different dosage rates, dry leaves powder for $P$. harmala at highest dosage rate and sheep manure at modest dosage rate. The highest shoot length was achieved in plants treated with dry leaves powder of $D$. stramonium at highest dosage rate with $80 \%$ increase, followed by Vydate ${ }^{\circledR}$ achieving $76.9 \%$ increase. Statistically, insignificant differences were noticed between such values and those of healthy control. With regard to garlic root parameters, root weight was more affected with the tested soil amendments than root length. All tested treatments significantly increased root weight except in case of fresh chopped leaves of $P$. harmala at lowest dosage rate. 
Table (2): Effect of organic soil amendments on growth parameters of garlic plants infected with Ditylenchus dipsaci under greenhouse conditions.

\begin{tabular}{|c|c|c|c|c|c|c|c|c|c|c|c|}
\hline \multirow[b]{2}{*}{ Treatments } & \multirow{2}{*}{$\begin{array}{l}\text { Dose } \\
\text { gm. }\end{array}$} & \multicolumn{2}{|c|}{ Shoot } & \multicolumn{4}{|c|}{ Root } & \multicolumn{4}{|c|}{ Bulb } \\
\hline & & $\begin{array}{l}\text { Valght } \\
\text { (gm) }\end{array}$ & Increase \% & $\begin{array}{c}\text { Length } \\
\text { (cm) }\end{array}$ & Increase\% & $\begin{array}{c}\text { Valght } \\
(\mathrm{gm})\end{array}$ & Increase $\%$ & $\begin{array}{l}\text { Length } \\
\text { (cm) }\end{array}$ & Increase\% & $\begin{array}{c}\text { Voight } \\
\text { (gm) }\end{array}$ & $\begin{array}{c}\text { Increa } 69 \\
\%\end{array}$ \\
\hline \multirow{2}{*}{$\begin{array}{l}\text { Dawra sramonium } \\
\text { (F) }\end{array}$} & 5 & $2.5000 e^{\prime} g$ & 103.2 & 33.6 bodet & 46.7 & 7.7 oodefg & 126.5 & $30.1 \mathrm{abc}$ & 79 & 1.2 bose & 500.0 \\
\hline & $\begin{array}{l}10 \\
15\end{array}$ & 3.7 fgnilk & $\begin{array}{l}196.8 \\
282.3\end{array}$ & 35.2 bodetg & $\begin{array}{l}53.7 \\
69.4\end{array}$ & 8.3 coetg & 144.1 & 35.9 codef & 28.7 & 1.3 bodet & 550.0 \\
\hline \multirow{3}{*}{$\begin{array}{l}\text { Daura suamonium } \\
\text { (D) }\end{array}$} & 5 & 2.1 abcoe & 67.7 & 32.2 bodet & 40.6 & $6.1 \mathrm{bc}$ & 78.8 & 33.3 bode & 19.4 & 1.3 bosetg & 5500 \\
\hline & 10 & 2.6 odefon & 1113 & 37.4 odetg & 63.3 & 5.70 & 67.1 & $30.1 \mathrm{abc}$ & 79 & 10000 & 4000 \\
\hline & 15 & 3.7 fghlik & 195.2 & $41.1 \mathrm{fg}$ & 79.5 & 7.5 boots & 1212 & 34.3 bose & 229 & 1.5 odetgn & 650.0 \\
\hline \multirow{3}{*}{$\begin{array}{c}\text { Peganum harmala } \\
\text { (F) }\end{array}$} & 5 & $1.0 \mathrm{a}$ & -16.7 & 30.0 abod & 31.0 & $32 \mathrm{a}$ & -7.1 & $26.0 \mathrm{a}$ & -6.8 & $0.4 \mathrm{a}$ & 100.0 \\
\hline & 10 & $1.1 \mathrm{a}$ & -11.3 & $25.6 \mathrm{ab}$ & 16.2 & $5.6 \mathrm{~b}$ & 64.1 & 33.3 bove & 19.4 & $0.7 \mathrm{ab}$ & 250.0 \\
\hline & 15 & 2.5 bodefg & 98.4 & 30.5 abod & 33.2 & 7.1 bode & 107.6 & $30.7 \mathrm{abod}$ & 10.0 & $1.0 \mathrm{bcd}$ & 400.0 \\
\hline \multirow{3}{*}{$\begin{array}{c}\text { Peganum hamala } \\
\text { (D) }\end{array}$} & 5 & 2.5 bodetg & 1000 & $34.2000 e^{\prime}$ & 49.3 & $9.7 \mathrm{fgh}$ & 1859 & 36.8 def & 319 & $1.8 \mathrm{fgh}$ & 800.0 \\
\hline & 10 & 3.1 costg & 150.0 & 32.2 bosef & 40.6 & $9.8 \mathrm{gh}$ & 187.6 & $31.3 \mathrm{abor}$ & 12.2 & 2.41 & 11000 \\
\hline & 15 & 3.2 osefg & 1548 & 29.9 abod & 30.6 & 90 eftg & 165.3 & 33.4 bose & 19.7 & $19 \mathrm{ghl}$ & 850.0 \\
\hline \multirow{3}{*}{$\begin{array}{l}\text { Tageres minuta } \\
\text { (F) }\end{array}$} & 5 & 2.0 abcoe & 58.1 & 349 bodetg & 52.4 & 90 efg & 164.1 & $31.1 \mathrm{abod}$ & 11.5 & $20 \mathrm{hl}$ & 900.0 \\
\hline & 10 & 3.7 ghllk & 201.6 & 37.2 odefg & 62.4 & 9.1 etg & 167.1 & $38.5 \mathrm{ef}$ & 38.0 & $1.9 \mathrm{ghl}$ & 850.0 \\
\hline & 15 & 2.5 boodefg & 103.2 & 35.6 odetg & 55.5 & 6.6000 & 929 & $28.2 \mathrm{ab}$ & 1.1 & $2.1 \mathrm{hl}$ & 9500 \\
\hline \multirow{3}{*}{$\begin{array}{l}\text { Tageies minuta } \\
\text { (D) }\end{array}$} & 5 & 3.3 etghil & 164.5 & 38. 1 od etg & 66.4 & 7.4 bosef & 117.1 & $31.2 \mathrm{abod}$ & 11.8 & 1.2 bose & 500.0 \\
\hline & 10 & $43 \mathrm{k}$ & 248.4 & 38.4 odetg & 67.7 & 7.1 bode & 108.8 & $41.5 f$ & 48.7 & $19 \mathrm{ghl}$ & 850.0 \\
\hline & 15 & 3.5 fghll & 182.3 & 38.7 defg & 69.0 & $8.5 \mathrm{defg}$ & 150.0 & $300 \mathrm{abc}$ & 7.5 & 1.6 defgh & 700.0 \\
\hline & 2 & 3.2 defका & 161.3 & 35.6 odefg & 55.5 & 7.5 bodetg & 121.8 & $30.5 \mathrm{abod}$ & 9.3 & $1.7 \mathrm{efgh}$ & 750.0 \\
\hline \multirow[t]{2}{*}{ Poutry manure } & 4 & $3.8 \mathrm{nIk}$ & 209.7 & 35.4 bosetg & 54.6 & 7.6 bodetg & 124.7 & 30.8 abod & 10.3 & $1.8 \mathrm{~kg}$ & 800.0 \\
\hline & 6 & 3.2 odefghl & 154.8 & 32.6 bodet & 42.4 & 7.3 bode & 115.3 & $31.5 \mathrm{abod}$ & 129 & 1.6 defgh & 700.0 \\
\hline \multirow{3}{*}{ Sheep manure } & 5 & $20 \mathrm{abod}$ & 59.7 & 31.7 bose & 38.4 & $5.6 \mathrm{~b}$ & 63.5 & $28.3 \mathrm{ab}$ & 1.4 & 1.0 bod & 400.0 \\
\hline & 10 & $19 a b c$ & 53.2 & $29.4 a b c$ & 28.4 & 5.80 & 71.8 & 30.5 abod & 9.3 & $0.9 \mathrm{bc}$ & 350.0 \\
\hline & 15 & 2.4 botet & 93.5 & 33.4 bodet & 459 & 6.7 bode & 98.2 & 25.9 a & -3.6 & $1.0 \mathrm{bor}$ & 400.0 \\
\hline Oxamyl & 1 & $4.4 \mathrm{~kg}$ & 254.8 & 40.5 efg & 76.9 & 7.1 bode & 108.8 & $31.4 \mathrm{abod}$ & 12.5 & $1.6 \mathrm{efgh}$ & 700.0 \\
\hline Check & & $12 \mathrm{ab}$ & 0.0 & $229 \mathrm{a}$ & 0.0 & $3.4 \mathrm{a}$ & 0.0 & $279 a b$ & 0.0 & $0.2 \mathrm{a}$ & 0.0 \\
\hline Healthy & & $4.8 \mathrm{~K}$ & 287.1 & $43.6 \mathrm{~g}$ & 90.4 & 8.8 defg & 160.0 & 35.1 ode & 25.8 & $1.7 \mathrm{efgin}$ & 750.0 \\
\hline
\end{tabular}

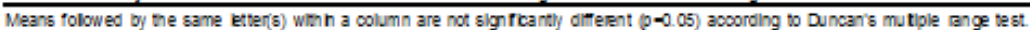

F- Fresh chopped leaves.

D- Dry leaves powder. 
The highest root fresh weight was recorded in the plants treated with fresh chopped leaves of $D$. stramonium at highest dosage rate by $246.5 \%$ increase followed by dry leaves powder of $P$. harmala at modest and lowest dosage rates with $187.6 \%$ and $185.9 \%$ increase, respectively; however, a such increase was $160 \%$ in case of healthy control. On the other hand, most tested soil amendments at different dosage rates caused insignificant \% increase in root lengths except in case of modest dosage rate of fresh chopped leaves of $D$. stramonium and $T$. minuta and dry leaves powder of $T$. minuta and lowest dosage rate of dry leaves powder of $P$. harmala. All soil amendment treatments remarkably achieved the highest significant increase in bulb weights over the check in comparison to those of the other plant growth criteria with increase ranged between 100-1150\%.

\section{Discussion}

Amending soil with fresh chopped leaves or dry leaves powder of the tested plants and poultry manure were very effective in suppressing stem nematodes in varying degree and enhanced growth and yield of garlic compared to the untreated control.

The nematode reproduction factor was decreased as the soil amendment dosage rate was increased. These results are in agree with those obtained by Kheir et al., (2000), Hosseininejad, (2004); Radwan, et al. (2007); Ntalli et al. (2010); Karmani et al. (2011); Cavoski et al. (2012); Onyeke and Akueshi (2012) and Saeed and Shawkat (2014).

Fresh chopped leaves of $D$. stramonium and $T$. minuta were more effective than dry leaves powder in reducing nematode population. It is possible that the main plant compound responsible for the nematicidal effect as $\alpha$-therthienyl in Tagetes species was destroyed during the preparing process of powder (Wang et al., 2007). But the reverse was true for $P$. harmala and that may be attributed to amount increase of nematicidal compounds in case of dry leaves powder or to the slow and continuous release of the nematicidal compounds in soil. $P$. harmala achieved the strongest nematicidal activity against $D$. dipsaci on garlic under greenhouse conditions, followed by $D$. stramonium at different dosage rates in comparison to that of the check. This could be attributed to production of strong nematicidal substances like harmal's alkaloids include $\beta$-carboline as harmine, harmaline, harmalol, harmol and harman and quinazolines as vaccine and vasicinone (El-Hassan et al., 2013). Active ingredients of $D$. stramonium are atropine, nicotine, hyoscyamine and scopolamine which are classified as deliriants, or anticholinergics (Oduor- Owino, 1993 and Archana and Prasad, 2014) and amending soil with leaves of such plant was effective against $M$. incognita (Chattopadhyay, 1991; Radwan, et al., 2007; Hussain, et al., 2011 and Saeed and Shawkat, 2014). The nematicidal activity of $T$. minuta can be attributed to its contents of E-tagetenone, jasmolins I and II, limonene, myrcene, beta- 
caryophyuenc, cinerins I and II, a -terthienyl, bithienyl, 5(-ent-1-ol)-2,2-bithienyl, sigma-4, 22-dien-3-beta-ol, 5-(4-acetoxy-1-butenyl) -2,2-bithienyl, -butyl-2,20bithienyl and 5-(3-buten-1-eynyl)-2,20-bithienyl (Uhlenbroek and Bijloo, 1958 \& 1959; Gommers and Bakker, 1988; El-Gengaihi et al., 2001 and Archana and Prasad, 2014). Amending soil with poultry manure significantly reduced nematode population and improved plant growth. This result is in agreement with the findings of Kablanand Noe (1993), El-Zawahry (2000), Ibrahim and Ibrahim (2000), Maareg et al. (2000), Devi and Hassan (2002), Farahat et al. (2008), Karmani et al. (2011), Farahat et al. (2012) and Saeed and Shawkat (2014).

Poultry manure at all dosage rates was better than sheep manure in controlling stem nematode and improving plant growth. These findings are in agreement with the work of Miano (1999) and Karmani et al. (2011a\&b). The action of organic manures against soil nematodes is mainly attributed to its contents of volatile fatty acids, phenols, amino acids, ammonia, nitrites and gasses which released during decomposition enhancing soil populations of micro-organisms antagonistic to nematodes (Badra, et al., 1979; Mian and Rodrequez-Kabana, 1982; Lazarovits et al., 2001; Oka and Pivonia, 2002 and Farahat et al., 2008).

The increase in growth of $D$. dipsaci infected garlic plants grown in treated soils compared to the untreated soils may be attributed partly to nematode control and to beneficial effects on soil nutrients, soil physical conditions and soil biological activity (Akhtar and Malik, 2000; Ramesh et al., 2009; Oka, 2010 and Moosavi, 2012). Therefore, the use of fresh chopped leaves or dried leaves powder of the tested plants and poultry manure may gave promise tools to suppress nematode populations and may provide environmentally safe and economically cheap alternatives to chemicals. Further investigations are necessary to confirm their effectiveness under field conditions before final decision.

\section{References}

Abdul Latif, M.; Sharmina Akter; Shahjahan Kabir, M.; Ansar Ali, M.; Anwar Hossain, M. and Loothfor R., (2006). Efficacy of some organic amendments for the control of ufra disease of rice. Bangladesh $\mathrm{J}$. Microbiol., 23 ( 2): 118-120.

Ahmad, F.; Rather, M. A. and Siddiqui, M. A. (2007). Impact of organic soil amendments and nematicides on Meloidogyne javanica infecting tomato. Indian J. of Nematol., 37: 55-57.

Akhtar, M. and Mahmood, I. (1996). Organic amendments in relation to nematode management with particular reference to India. Intrgd. Pest Mngmt., 1 (4): 201-215.

Akhtar, M. and Malik A. (2000). Roles of organic soil amendments and soil organisms in the biological control of plant-parasitic nematodes: a review. Bioresour. Technol., 74:35-47. 
Alam, M. M. (1990). Neem in biocontrol. In: NematodeBiocontrol (Aspects and Prospects) (Jairajpuri, M. S., Alam, M. M. and Ahmad, I. eds.). CBS Publishers and Distributers, Delhi, India, 17-40 PP.

Anastasiadis, I. A.; Giannakou, I. O.; Prophetou Athanasiadou, D. A. and Gowen, D. A. (2008). The combined effect of the application of a biocontrol agent Paecilomyces lilacinus, with various practices for the control of rootknot nematodes. Crop Protection, 27, 352-361.

Archana, U. S. and Prasad, D. (2014). Management of plant-parasitic nematodes by the use of botanicals. J. Plant Physiol Pathol., 2:1.

Awadh, G. M.; Saeed, M. R.; Najy, A. and Saleh, A. M. ( 2008). In-vitro nematicidal activity of some selected plants on stem nematode Ditylenchus dipsaci (Tylenchida: Tylenchidae). Yemeni J. of Biological Sci. 4(1):141150.

Badra, T.; Saleh, M.A. and Oteifa, B.A. (1979). Nematicidal activity and composition of some organic fertilizers and amendments. Rev. Nematol.,2: 29-36.

Cavoski, I.; Chami, Z. A.; Bouzebboudja, F.; Sasanelli, N.; Simeone, V.; Mondelli, D.; Miano, T.; Sarais G.; Ntalli, N. G. and Caboni, P. (2012). Melia Azederach controls Meloidogyne incognita and triggers plant defence mechanisms on cucumber. Crop Protect., 35: 85-90.

Chattopadhyay, P. R. (1991). Nematicidal properties of some plant materials on tomato (Lycopersicon esculentum cultivar local) infested with Meloidogyne incognita . Geobios (Jodhpur), 18(5/6): 232-236.

Chitwood, D.J. (2003). Research on the plant parasitic nematode biology conducted by the United States, Department of Agriculture- Agricultural Research Service. Pest Manage Sci., 59:748-753.

Devi, L. S. and Hassan, M. G. (2002). Effect of organic manures singly and in combination with Trichoderma viride against root knot nematode, Meloidogyne incognita of soybean (Glycine max L. Mrill). Indian J. Nematol., 32 (2): 190-192.

El-Gengaihi, S. E.; Osman, H. A.; Youssef, M. M. A. and Mohamed, S. M. (2001). Efficacy of Tagetes species extracts on the mortality of the reniform nematode, Rotylenchulus reniformis. Bull NRC, Egypt, 26, 441-450.

El-Hassan, M.; Ferji, Z. and Idrissi, H. L. (2013). Anti-nematode effect assessment of Peganum harmala based products against Meloidogyne javanica on melon. J. of Biolo, Agric. and Healthcare, 3 (5):2224-3208. 
El-Zawahry, A. M. (2000). Effect of organic manure on infection of faba bean by root knot nematode. Assiut J. Agri. Sci., 31 (4): 79-88.

Farahat, A. A.; Al-Sayed, A. A.; EL-Beltagi, H. S. and Nomair, M. M. (2012). Impact of organic and inorganic fertilizers on nematode reproduction and biochemical alterations on tomato. Not. Sci. Biol., 4(1):48-55.

Farahat, A. A.; El-Naggar, H. I.; Hendy, H. H. and El-Ghonaimy, A. M. (2008). Management of the root-knot nematode Meloidogyne incognita infecting peach, Prunus persica under greenhouse condition. Egypt. J. of Agronematol., 6(2): 127-146.

Giannakou I.O.; Karpouzas, D.G. and D. Prophetou-Athanasiadou, (2004). A novel non-chemical nematicide for the control of root-knot nematodes. Applied Soil Ecology,26, 69 -79.

Gommers, F. J. and Bakker, J. (1988). Physiological diseases induced by plant responses or products. In: Poinar Jr., G.O., Jansson, H.-B. (Eds.), Diseases of Nematodes, vol. 1.CRC Press, Boca Raton, FL., pp. 3-22.

Hassan, A.; Al-naser, Z. A. and Al -asaas, K. (2015). Effect of some plant extracts on larval mortality against the stem nematode (Ditylenchus dipsaci) and compared with synthetic pesticides. Int.J. ChemTech Res., 7(4): 19431950.

Hosseininejad, S. A. (2004). Effect of neem, Azadirachta indica, on root-knot nematode, Meloidogyne javanica, infesting tomato. App. Entomol. and Phytopathol., 71: 69-89.

Hussain, M. A.; Mukhtar, T. and Kayani, M. Z. (2011). Efficacy evaluation of Azadirachta indica, Calotropis procera, Datura stramonium and Tagetes erecta against root-knot nematodes Meloidogyne incognita. Pak. J. Bot., 43: 197-204.

Ibrahim, A. A. M. and Ibrahim, I. K. A. (2000). Evaluation of non-chemical treatments in the control of Meloidogyne incognita on common bean. Pak. J. Nematol., 18 (1-2): 51-57.

Ibrahim, I.K.A.; EL-Saedy, M.A.M. and Asmaa, A. M. (2007). Control of the rootknot nematode Meloidogyne incognita on sunflower plants with certain organic plant materials and biocontrol agents. Egypt. J. Phytopathol., Vol. 35 , No. 1 , pp. 13-24.

Ibrahim, S.K. and Traboulsi, A.F. (2009). The impact of solarization integrated with plant bio-fermentation on root-knot nematodes. Lebanese Science Journal., 10( 2): 59-69. 
Insunza, V. (1988). Nematicidal activity of Chilean plants: in vitro tests on Ditylenchus dipsaci. International NematologyNetwork Newsletter,7: 44-46.

Insunza, V. (1994). Propiedades nematicidas de plantas chilenas. I. Evaluación en bioensayos con tres nematodos fitoparásitos. Fitopatología, 29:44-45.

Insunza, V. and Valenzuela, A. (1995). Control of Ditylenchus dipsaci on garlic (Allium sativum) with extracts of medicinal plants from Chile. Nematrop., 25: $35-41$.

Ishaku, B. C. and Ahaji, M. B. (2013). Evaluation of organic soil Amendments on the growth and yield of Meloidogyne incognita on cowpea. Plants J. of Biol. Agric. and Healthcare ISSN 2224-3208 (Paper) ISSN 2225-093X (Online) Vol.3, No.3.

Kagai, K. K. (2009). Management of root-knot nematodes and weeds using different amendments in greenhouse grown (Asclepias tuberosa L.). M.Sc. Thesis. Horticulture, Egerton Univ., 68pp.

Kaplan, M.; Noe, J.P. (1993). Effects of chicken excrement amendments on Meloidogyne arenaria, J.Nematol., 25,71-77.

Karmani, B. K.; Jiskani, M. M.; Khaskheli, M. I. and Nizamani, Z. A. (2011). Effect of organic amendments on plant growth and gall development in eggplants inoculated with root-knot nematode (Meloidogyne incognita). Pak. J. Phytopathol., 23 (2):131-137.

Karmani, B. K.; Jiskani, M. M.; Khaskheli, M. I. and Wagan, K. H. (2011). Influence of organic amendments on population and reproduction of root knot nematode, Meloidogyne incognita in eggplants. Pak. J. Agri. Agril. Engg. Vet. Sci., 27 (2): 150-159.

Kheir, A. M.; AL-Sayed, A. A. and EL-Naggar, H. I. (2000). Nematicidal potential of some ground ornamental plants against Meloidogyne incognita on sunflower. Egypt. J. of Agronematol., 4(1\&2): 31-40.

Lazarovits, G.; Tenuta, M. and Conn, K. L. (2001). Organic amendments as a disease control strategy for soil borne disease of high-value agricultural crops. Australasian Plant Pathol., 30: 111.

Maareg, M. F.; Salem, F. M. and Ebieda, A. M. (2000). Effect of certain organic and inorganic amendments on Meloidogyne javanica in sandy soil. Egypt. J. of Agronematol., 4(1\&2): 83-94.

Mian, I. H. and Rodriguez-Kabana, R. (1982). Soil amendments with oil cakes and chicken litter for control of Meloidogyne arenaria. Nematrop., 12(2), 205220. 
Miano, D. W. (1999). Opmization of carbon:nitrogen ratios in organic soil amendments for the control of root-knot nematodes (Meloidogyne spp.) in tomato. Msc. Thesis University of Nairobi.

Moosavi, M. R. (2012). Nematicidal effect of some herbal powders and their aqueous extracts against Meloidogyne javanica. Nematrop., 42 (1): 48-56.

Muller, R. and Gooch, P. S. (1982). Organic amendments in nematode control. An examination of the literature. Nematrop.,12:319-326.

Nahar, M. S.; Huq, M. I.; Islam, M. S. and Hossain, M. H. (1996). Efficacy of organic soil amendment for the management of root-knot of tomato. Bangladesh J. of Plant Pathol., 12 (1-2):17-20.

Noling J.W. and Becker J.O. (1994). The challenge of research and extension to define and implement alternatives to methyl bromide. Journal of Nematology., 26: 573-586.

Ntalli, N.; Menkissoglu-Spiroudi, U. and Giannakou, I. (2010). Nematicidal activity of powder and extracts of Melia azedarach fruits against Meloidogyne incognita . Annals of App. Biolo., 156: 309-317.

Oduor-Owino, P. (1993). Effects of aldicarb, Datura stamonium, Datura metel and Tagetes minuta on the pathogenicity of root-knot nematode in Kenya. J. Crop Protec., 12(4): 315-317.

OEPP/EPPO, Bulletin (2008). Ditylenchus destructor and Ditylenchus dipsaci, 38: $363-373$.

Ojo, G.T. and Umar, I. (2013). Evaluation of some botanicals on root - knot nematode (Meloidogyne javanica) in tomato (Lycopersicon esculentum, Mill) in Yola Adamawa State, Nigeria. Biologic. Forum - An International J., 5(2): 31-36(2013).

Oka, Y. (2010). Mechanism of nematode suppression by organic soil amendments. A Rev. App. Soil Ecol., 44:101-115.

Oka, Y. and Pivonia, S. (2002). Use of ammonia-releasing compounds for control of the root-knot nematode. Nematol., 4: 65-71.

Onyeke, C. C. and Akueshi, C. O. (2012). Infectivity and reproduction of Meloidogyne incognita (Kofoid and White) Chitwood on African yam bean, Sphenostylis stenocarpa (Hochst Ex. A. Rich) Harms accessions as influenced by botanical soil amendments. Afri. J. of Biotechno., 11(67), pp. 13095-13103Publishing House, pp: 320-322.

Parihar, K.; Rehman, B. and Siddiqui, M. A. (2012). Impact of organic additives for sustainable management of root-knot nematode in bottle gourd. Biosciences International., 1 (4): 102-105. 
Radwan, E.K.; El-Maadawy, and Abu-Elamayem, M.M. (2007). Comparison of the nematicidal potentials of dried leaves of five plant species against Meloidogyne incognita infecting tomato. Nematologia Medit., 35:81-84.

Ramesh, P.; Panwar, N. R.; Singh, A. B. and Ramana, S. (2009). Effect of organic nutrient management practices on the production potential, nutrient uptake, soil quality, input-use efficiency and economics of mustard (Brassica juncea). Indian J. Agric. Sci., 79:40-44.

Rather, M. Z.; Ahmed, F. and Siddiqui, M. A. (2008). Nematicidal effect of chopped leaves of some selected plants against root-knot nematode, Meloidogyne incognita on tomato. International J. of Plant Sci., 3( 2): 339341.

Saeed, M. R. and Shawkat, J. N. (2014). Evaluation of nematicidal effect of some botanicals powders and poultry manure against the root-knot nematode Meloidogyne incognita in tomato plants under greenhouse conditions. Egypt. J. Agronematol., 13 (1):160 -171.

Southey, J. F. (1986). Laboratory Methods for Work with Plant and Soil Nematodes. HMSO, London, 5-30.

Sundararaju P, Padmanaban, B. and Sathiamoorthy, S. (2003). Efficacy of certain botanicals against root-lesion nematode, Pratylenchus coffeae in banana. Nematologia Mediterranea 31: 201-205.

Tsay, T.T.; Wu, T.S. and Lin, Y.Y. (2004). Evaluation of Asteraceae plant for control of Meloidogyne incognita. J. of Nematol., 36: 36-41.

Uhlenbroek, J. H. and Bijloo, J. D. (1958). Investigations on nematicides. I: Isolation and structure of a nematicidal principle occurring in Tagetes roots.Rec. Trav.Chim., Pays-Bas, 77:1004-9

Uhlenbroek, J. H. and Bijloo, J. D. (1959). Investigations on nematicides. II: Structure of a second nematicidal principle isolated from Tagetes roots. Rec. Trav. Chim., Pays-Bas, 78:382-90.

Verma, A.C. and Khan, M. N. (2004). Potentiality of botanicals for managing Meloidogyne incognita in Ocimum canum. Annals of Plant Prot. Sci., 12: 464-465.

Wangs, K.H.; Hooks, C.R. and Ploeg, A. (2007). Protecting crops from nematode pests: using marigold as an alternative to chemical nematicides. Cooperative Extension Service. Plant Disease, 35:1-6.

Wani, A.H. (2006). Management of root-knot nematode, Meloidogyne incognita on okra and lentil by soil amendment with oil cakes and leaves of different plants. Nematologia Medit., 34: 83-89. 
Washira, P. M.; Kimenju, J. W.; Okoth, S. A. and Miley, R. K. (2009). Stimulation of nematode destroying fungi by organic amendments applied in management of plant parasitic nematode. Asian J. of Plant Sci., 3: 153-159.

Whitehead A.G. (1998). Plant nematode control. CAB International Wallingford, UK, 384 pp.

Youssef, M. M. A. and Lashein, A. M. S. (2013). Efficacy of different medicinal plants as green and dry leaves and extracts of leaves on root knot nematode, Meloidogyne incognita infecting eggplant. Eurasian J. of Agri. and Environ. Medic., 2(1): 10-14.

Zouhar M.; Douda O.; Lhotský D. and Pavela R. (2009). Effect of plant essential oils on mortality of the stem nematode (Ditylenchus dipsaci). Plant Protect. Sci., 45: 66-73. 


\section{الملخص العربي}

تقييم تأثير إضافة بعض الأسمدة العضوية النباتية والحيوانية للتربة في مكافحة نيماتودا السوق والأبصال (دايتيلنكس ديبساسي) على نبات الثوم تحت ظروف الصوبة

$$
\begin{aligned}
& \text { محمد راوح محمد سعيد } \\
& \text { قسم وقاية النبات - كلية الزراعة - جامعة صنعاء }
\end{aligned}
$$

تم تقيم إضافة بعض الأسمدة العضوية كمفروم أوراق طازجة أو مطحون أوراق جافة لنباتات

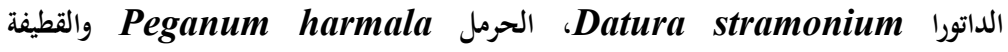
وسبلة الدواجن والأغنام مقارنة بالمبيد النيماتودي الفايديت في مكافحة

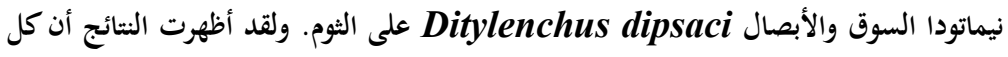

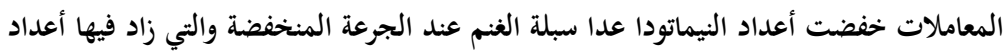

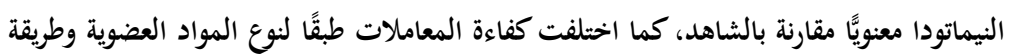

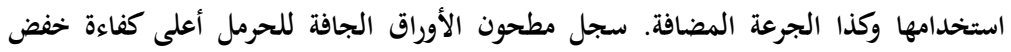

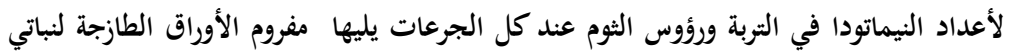

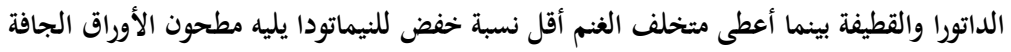

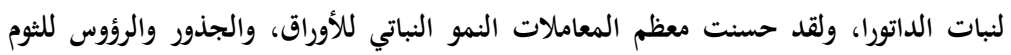

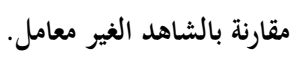

